\title{
GENETIC STRUCTURE OF THE KHAKASS SUB-ETHNIC GROUPS FROM AUTOSOMAL DNA MARKERS AND SURNAMES
}

\author{
Maria B. Lavryashina ${ }^{a, *}$, Marina V. Ul'yanova ${ }^{a}$, Olga A. Balaganskaya ${ }^{b}$, Elena V. Balanovska ${ }^{c}$ \\ ${ }^{a}$ Kemerovo State University, \\ Krasnaya Str. 6, Kemerovo, 650043 Russian Federation \\ ${ }^{\mathrm{b}}$ Vavilov Institute of General Genetics, \\ Gubkina Str. 3, Moscow, 119333 Russian Federation \\ ${ }^{c}$ Research Centre of Medical Genetics \\ Moskvorechie Str. 1, Moscow, 115478 Russian Federation \\ * e-mail:1mb2001@mail.ru
}

Received September 29, 2016;

Accepted in revised form November 11, 2016;

Published December 30, 2016

\begin{abstract}
The authors discussed the results of study of population genetic structure of Khakass sub-ethnic groups - indigenous population of the Republic of Khakassia. The gene pool is studied according to two classes of markers: autosomal DNA (CCR2*rs1799864, CCR5*rs333, ACE1*rs4646994, PLAT*rs4646972, noA25*rs, PV92*rs3138523, ApoA1*rs3138522, no B65*rs, no F13B*rs) and quasigenetic markers (surnames). Total sample size was 249 persons for autosomal DNA dataset, and 9693 persons for the surnames dataset. Four Khakass sub-ethnic groups - Kachins, Koybals, Kyzyls, and Sagays - were investigated. Both classes of markers provided similar results on the subdivision of Khakass sub-ethnic groups and genetic relationships between them. Analysis of autosomal DNA markers showed statistically significant differences of allele frequencies. Interpopulation genetic variation (GST) of the Khakass populations was $2.10 \%$. The largest genetic distances were observed when comparing Sagays and Kyzyls $(\mathrm{d}=0.032)$. The least genetic distances were observed when comparing samples of Kachins and Koybals $(\mathrm{d}=0.032)$. According to the surnames dataset, the similarity index (Ri) is minimal in the pair "Sagays - Kyzyls" and is maximal in a pair of "Kachins - Koybals". Genetic distances characterizing the differences between sub-ethnic groups, decrease, and kinship coefficient, which reflects the similarity increases in the following series: Sagays, Kyzyls, Kachins, and Koybals.
\end{abstract}

Keywords: indigenous population, quasigenetic markers peptides, enzymic hydrolysis, biotechnological methods

DOI: $10.21603 / 2500-1418-2016-1-2-78-84$.

\section{INTRODUCTION}

Work of team headed by Yu.G. Rychkov [1] laid the foundation of intensive research of gene pools of the indigenous peoples of South Siberia. Since then, a huge amount of data was accumulated characterizing the population genetic structure of the South Siberian peoples according to different genetic systems: autosomal DNA markers [2, 3], mitochondrial DNA markers [4, 5], Y-chromosome markers [6-9], X chromosome markers [10], quasigenetic markers - surnames [11, 12]. Formed biobanks and databases of Siberian population gene frequencies are increasingly in demand by the international scientific community [13] to solve the fundamental [14] and applied [15] problems. The result of these studies was understanding of necessity to study the small-numbered nations (in this article, we will use the term "sub-ethnos" to refer to them), joined under territorial exoethnonyms.

Exoethnonyms such as "Altaians", "Khakass", and "Shors" are names of the indigenous population of various geographical areas - the Altai-Sayan highlands, Khakass-Minusinsk hollow, Mountain Shoria. At the same time the modern Altaians population includes four sub-ethnic groups having the status of indigenous peoples - Kumandins, Telengits, Tubalars, Chelkans and fifth - the title for the Republic of Altai - the Altai-Kizhi. Khakass include four sub-ethnic groups - Kachins, Koybals, Kyzyls, and Sagays. Shors have two sub-ethnic groups - mountain taiga and Abakanian. It is obvious that in the recent past namely the small-numbered peoples reflected features of population of Southern Siberia, so the analysis of gene pools of smallnumbered peoples may open a new page in its ethnic history and microevolution of its populations. Khakass is the indigenous population of the Republic of Khakassia (hereinafter - RK). Emergence of the ethnic term "Khakass" and validity of its use as a selfdesignation of South Siberian Turks of the KhakassMinusinsk hollow causes debates in historical and ethnographic environment. According to some researchers, this term is endogenous, as it existed previously as the name of one of the oldest ethnic groups - ethnonym "Khakass" was mentioned in the Chinese written sources of the VI - XII centuries [16]. According to another view, it is exoethnonyms, and its implementation as a self-designation of ethnic genetics of RK is artificial. [17]

Please cite this article in press as: Lavryashina M.B., Ul'yanova M.V., Balaganskaya O.A., Balanovska E.V. Genetic structure of the Khakass subethnic groups from autosomal DNA markers and surnames. Science Evolution, 2016, vol. 1, no. 2, pp. 78-84. doi: 10.21603/2500-1418-2016-1-2-78-84. Copyright (C) 2016, KemSU. This is an open access article distributed under the terms of the Creative Commons Attribution 4.0 International License (http:// creativecommons.org/licenses/by/4.0/), allowing third parties to copy and redistribute the material in any medium or format and to remix, transform, and build upon the material for any purpose, even commercially, provided the original work is properly cited and states its license. This article is published with open access at http:/ science-evolution.ru/ 
The process of formation of Khakass ethnos included several stages. "Kyrgyz" stage is connected with the existence of the Kyrgyz State (VI-XIII centuries). The Yenisei Kyrgyz, one of the ancient cultural peoples of Central Asia, were among the ancestors of the modern Khakass and Kyrgyz people, and dispersed among many stock-raising peoples of the Sayano-Altai. "Hongoray" stage [18] covers formation of Khakass composed of several principalities (XIV-XVIII centuries). "Russian" stage began after accession of Khakass to Russia (XVIII XXI centuries). "Russian" stage is characterized by pronounced consolidation of indigenous population of the Khakass-Minusinsk hollow under official ethnonym "Khakass" within the province, district, county, autonomous region and, finally, the Republic of Khakassia.

Division of Khakass into modern Kachins, Sagays, Koybals, and Kyzyls was accepted at the beginning of the XVIII century and was based on names of the largest Khakass seoks: khaas, sagay, khoybals, khyzyl [19]. However, formation of these sub-ethnic groups has its roots in the period preceding appearance of Russian people on the Yenisei River [20] Kachins, which included seoks (genus) such as yzyr, pyuryut, sohs, khaskha, kyrgyz, and others, dominated politically and economically, and thus became the center of the consolidation processes of Khakass in the XVIII-XIX centuries. Kyzyls formed on the basis of Turkic-speaking population of valleys of White and Black Iyus, and Chulym. Formation of Koybals proceeded on the basis of the Turkic-speaking tribes and their assimilation of Samoyed and Ket-speaking population of the right bank of the Yenisei River. Koybals originally formed under the influence of Kachins, but since 1858, after the integration of their territories into the Sagayskaya Duma, their convergence with Sagays and Beltyrs intensified. By the end of the XIX century Beltyrs become to move closer to Sagays who expanded their territory at the expense of assimilation of population living on the left tributaries of the river Abakan, and in the XX century the ethnicon "sagays" spread to Beltyrs. Descendants of Birusins and Shors were also involved in the formation of the sagay group [20].

Official population censuses indicate the number of Khakass in Russia: as of 2002 - 75.6 thousand people, as of 2010 - 72.9 thousand people, including in the Republic of Khakassia - 63.6. All-Russian population censuses do not considered Khakass belonging to individual sub-ethnic groups. According to the calculated data [21], at the beginning of the XXI century, Sagay subethnic group dominates numerically, but four sub-ethnic group still persist and have areas of compact dwelling: Kachins and Kyzyls - Ordzhonikidze and Shirinsky districts of RK, Koybals - Beysky district of RK, Sagays Askizsky and Tashtypsky districts of RK (Fig. 1). Currently, Khakass people are characterized by significant inter-ethnic mixing, as a result of marriages between members of individual sub-ethnic groups, as well as the common tendency to the loss of self-designations Kachins, Kyzyls, Koybals, and Sagays.

According to the physical anthropology data, Khakass are generally classified as South Siberian Mongoloids, but their sub-ethnic groups are heterogeneous: The South Siberian variant is predominating among Kachins and Koybals, and is noticeably weakened among Sagays and Kyzyls [22]. With regard to ethnic genetics, a problem about genetic reality of the existence of Khakass subethnic groups is still open. Previously we have investigated the gene pools of Kachins, Koybals, and Sagays according to data on Y-chromosome polymorphism - one of the most informative genetic systems in the arsenal of ethnic genetics and ethnic genetics $[9,23]$. The results obtained indicate a significant genetic subdivision of Khakass sub-ethnic groups $\left(\mathrm{F}_{\mathrm{ST}}=30.3 \%\right)$ : the Khakass gene pool is a leader among the peoples of South Siberia in the degree of heterogeneity.

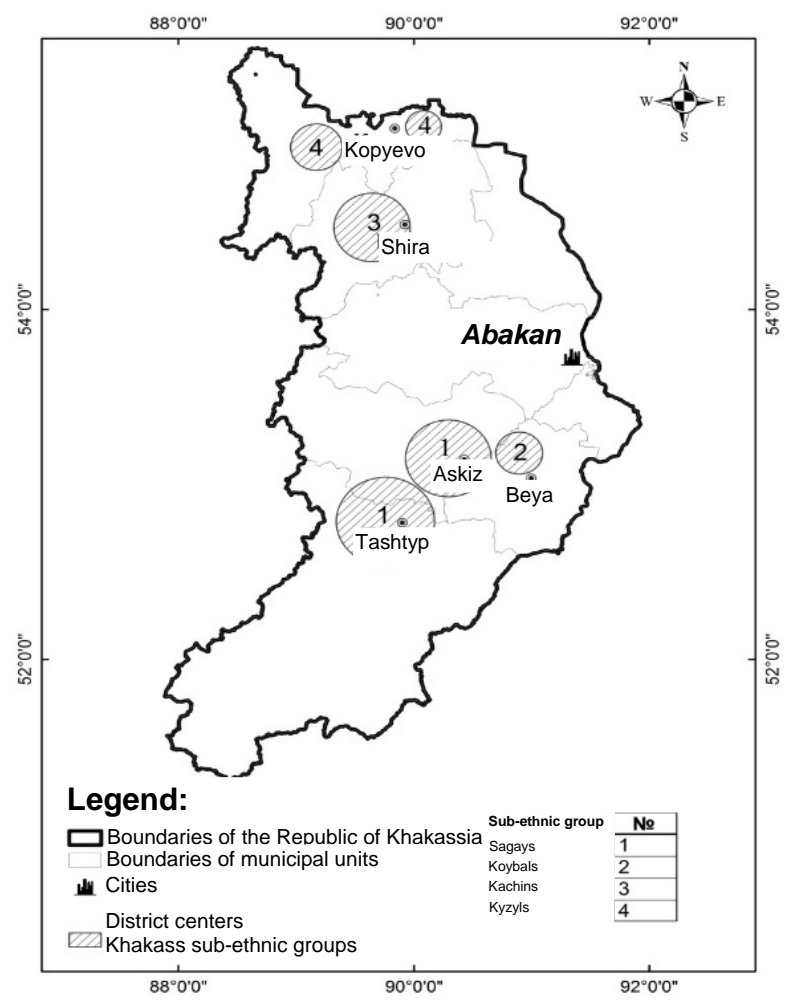

Fig. 1. The main areas of compact dwelling of Khakass sub-ethnic groups in the Republic of Khakassia. 
According to the physical anthropology data, Khakass are generally classified as South Siberian Mongoloids, but their sub-ethnic groups are heterogeneous: The South Siberian variant is predominating among Kachins and Koybals, and is noticeably weakened among Sagays and Kyzyls [22]. With regard to ethnic genetics, a problem about genetic reality of the existence of Khakass sub-ethnic groups is still open. Previously we have investigated the gene pools of Kachins, Koybals, and Sagays according to data on Y-chromosome polymorphism - one of the most informative genetic systems in the arsenal of modern population and ethnic genetics $[9,23]$. The results obtained indicate a significant genetic subdivision of Khakass sub-ethnic groups (FST=30.3\%): the Khakass gene pool is a leader among the peoples of South Siberia in the degree of heterogeneity.
The aim of this work was to continue research in this sense - to assess genetic reality of existence of Khakass sub-ethnic groups according to autosomal DNA markers and the surname pool.

\section{MATERIALS AND METHODS}

Material for the study was collected in the course of joint expeditions of the Kemerovo State University (Kemerovo, Russia) and the Medical Genetic Research Center (Moscow, Russia). The indigenous population of Khakassia was surveyed in places of its compact dwelling in five districts of the Republic of Khakassia - Askizsky, Beysky, Ordzhonikidze, Tashtypsky, and Shirinsky. Level of consolidation and subdivision of Khakass was assessed with the use of two types of markers (Table 1).

Table 1. Number of the studied samples of indigenous population of the Republic of Khakassia

\begin{tabular}{|c|c|c|c|}
\hline \multirow{2}{*}{ Khakass sub-ethnic groups, territories } & \multicolumn{2}{|c|}{ SURNAMES } & \multirow[b]{2}{*}{ DNA markers } \\
\hline & $\begin{array}{c}\text { Number of } \\
\text { surnames }\end{array}$ & $\begin{array}{c}\text { Number of surname } \\
\text { bearers }\end{array}$ & \\
\hline $\begin{array}{l}\text { Kachins } \\
\text { Shirinsky, Ordzhonikidze districts }\end{array}$ & 226 & 2370 & 126 \\
\hline $\begin{array}{l}\text { Koybals } \\
\text { Beysky district }\end{array}$ & 45 & 400 & 52 \\
\hline $\begin{array}{l}\text { Kyzyls } \\
\text { Ordzhonikidze district }\end{array}$ & 62 & 274 & 15 \\
\hline $\begin{array}{l}\text { Sagays } \\
\text { Askizsky, Tashtypsky districts }\end{array}$ & 439 & 6649 & 156 \\
\hline TOTAL FOR KHAKASS & 704 & 9693 & 349 \\
\hline
\end{tabular}

According to quasigenetic markers (surnames), the total sample included nearly 10 thousand people according to the household population registration books of rural municipalities (2000-2010). We analyzed the frequency and variety of surnames. Frequencies of common surnames were used to calculate isonymy index (Ri) [24], characterizing similarity (kinship) of groups.

The second type - genetic markers as such included autosomal gene loci: CCR2*rs1799864 (single nucleotide polymorphism); CCR5*rs333 (insertion-deletion polymorphism); ACE1*rs4646994, PLAT*rs4646972, no A25*rs, PV92*rs3138523, ApoA1*rs3138522, no B65*rs, no F13B*rs (Alupolymorphism). A single panel of 349 DNA samples of Khakass (Table 1) was studied. Genomic DNA isolated from venous blood by phenol-chloroform extraction was used as a material. Amplification results were evaluated using agarose gel electrophoresis. DNA detection was carried out using gels coloring with ethidium bromide followed by DNA visualization under UV light. In the course of CCR2*rs1799864 genotyping, a PCR product was subjected to prerestriction. Genetic distances ( $d$ [25]) between subethnic groups of Khakass were calculated on the basis of allele frequencies (DJgenetic software [Balanovsky et al., 2008]). Measure of their discrepancy was assessed using the indicator $G_{S T}$ [25].

\section{RESULTS AND THEIR DISCUSSION}

We found clear genetic differences between Khakass sub-ethnic groups. Allele frequencies of autosomal DNA markers were significantly different (Table 2). Alu-gene insertion in PLAT gene was registered among Kachins more frequently (0.521), than among Koybals (0.451, $\left.\chi^{2}=7.77, \mathrm{p}<0.01\right)$, Kyzyls (0.346, $\left.\chi^{2}=7.97, \mathrm{p}<0.01\right)$ and Sagays $\left(0.513, \chi^{2}=5.82\right.$, $\mathrm{p}<0.05)$ The Koybal population is characterized by a spread Alu-insertion in CDH13 - PV92 $(0.656)$ gene. Its frequency in the Kyzyls $\left(0.577, \chi^{2}=4.97, \mathrm{p}<0.05\right)$ and Kachins populations $\left(0.516, \chi^{2}=4.98, \mathrm{p}<0.05\right.$ ) was statistically much lower. Kyzyls are characterized by more frequent occurrence of Alu-insertion in ApoA1 gene, however, a statistically significant difference when compared with other Khakass sub-ethnic groups have been identified that may be due to the small number of samples of Kyzyls. As for the most numerous Khakass sub-ethnic group - Sagays, they have a very high frequency of allele $A$ in CCR2 (0.593). Differences between Khakass groups in this genetic marker were identified for all pairwise comparisons, without exception: between Sagays and Kachins (0.311, $\left.\chi^{2}=22.27, \mathrm{p}<0.001\right)$; between Sagays and Koybals $\left(0.333, \chi^{2}=10.58, \mathrm{p}<0.01\right)$; between Sagays and Kyzyls $\left(0.231, \chi^{2}=22.27, \mathrm{p}<0.001\right)$. It should be noted that frequency of allele $A$ in gene CCR2 revealed at Sagays exceeds not only all the estimates obtained in the 
study of the peoples of Altai and Mountain Shoria [2], but also frequencies for Tuvinians (0.047) [27], Uighurs (0.195 ) [28], Evenks (0.280) [29] and Yakuts (0.275) [30] well-known from the literature. As a whole, in the gene pools of all South Siberian peoples, an increased frequency of mutations in the gene CCR2 (from 0.231 for Kyzyls to 0.408 for Chelkans) [2] was identified as compared to the eastern Slavs (Russian, Ukrainians and Belarusians $0.07-0.08$ ) [27, 31] and many other peoples of the world. Furthermore, Sagays were in the group of leaders with respect to frequency of deletions (del32) in gene CCR5 (0.138). Statistically significant differences in this allele frequency were found between the two Khakass sub-ethnic groups - Sagays and Kachins $\left(0.045, \chi^{2}=6.92, \mathrm{p}<0.01\right)$.

Table 2. Frequencies of autosomal DNA markers in Khakass sub-ethnic groups

\begin{tabular}{|l|c|c|c|c|c|}
\hline \multirow{2}{*}{ DNA markers } & \multirow{2}{*}{ Alleles } & \multicolumn{4}{c|}{ Khakass sub-ethnic groups } \\
\cline { 3 - 6 } & & Kachins & Koybals & Kyzyls & Sagays \\
\hline CCR2*rs1799864 & Del32 & 0.311 & 0.333 & 0.231 & 0.593 \\
\hline CCR5*rs333 & $A$ & 0.045 & 0.088 & 0.154 & 0.138 \\
\hline ACE*rs4646994 & $I$ & 0.633 & 0.618 & 0.577 & 0.641 \\
\hline PLAT*rs4646972 & $I$ & 0.521 & 0.451 & 0.346 & 0.513 \\
\hline A25*rs- & $I$ & 0.178 & 0.078 & 0.077 & 0.080 \\
\hline PV92*rs3138523 & $I$ & 0.516 & 0.656 & 0.577 & 0.513 \\
\hline ApoA1*rs3138522 & $I$ & 0.893 & 0.902 & 0.962 & 0.875 \\
\hline F13B*rs - & $I$ & 0.754 & 0.814 & 0.769 & 0.699 \\
\hline B65*rs- & $I$ & 0.389 & 0.461 & 0.385 & 0.446 \\
\hline
\end{tabular}

Note. Del - deletion, $I$ - insertion, $A$ - adenine

Differences between Khakass sub-ethnic groups according to the studied autosomal DNA markers $G_{S T}=2.10 \%$ are comparable with the level of subdivision of the northern Altaians $\left(G_{S T}=1.75 \%\right)$ [32] and exceed the same indicator for Shors, Tuvinians, Buryats, and other peoples of Siberia. In this case the differences between the Eastern Slavic nations (Russian, Ukrainians and Belarusians) in the studied gene panel is 7 times lower $\left(G_{S T}=0.30 \%\right)$, than in Khakass. Significant differences between autosomal gene pools of Khakass sub-ethnic groups evidence in favor of genetic reality of their existence. That is also reflected by a matrix of genetic distances $(d)$ between these sub-ethnic groups calculated on the basis of allele frequencies (Table 3).
Genetic distances varied from 0.0077 when pairwise comparison of Kachins and Koybals to 0.0320 when pairwise comparison of Sagays and Kyzyls. Let us note that maximum differences identified between Sagays and Kyzyls correlate with geographical distances: ethnic areas of Sagays and Kyzyls are the most distant from each other. Sagays live in the southeast of Khakassia and Kyzyls live in the north-west (Fig. 1). At the same time, Sagays were the most genetically distant from other Khakass subethnic groups as well. Average genetic distances decrease in the following series: Sagays $(\bar{d}=0.0232)-$ Kyzyls $(\bar{d}=0.0172)-$ Kachins $(\bar{d}=0.0129)-$ Koybals $(\bar{d}=0.0115)$.

Table 3. Matrix of genetic distances $(d)$ between Khakass sub-ethnic groups (autosomal DNA markers)

\begin{tabular}{|l|c|c|c|c|}
\hline \multicolumn{1}{|c|}{ Sub-ethnic groups } & Kachins & Koybals & Kyzyls & Sagays \\
\hline Kachins & 0 & & & \\
\hline Koybals & 0.0077 & 0 & 0 & 0 \\
\hline Kyzyls & 0.0121 & 0.0089 & 0.0320 & 0.0232 \\
\hline Sagays & 0.0187 & 0.0189 & 0.0172 & \\
\hline $\begin{array}{l}\text { Average genetic } \\
\text { distances }(\bar{d})\end{array}$ & 0.0129 & 0.0115 & & \\
\hline
\end{tabular}

Study of the pool of surnames in the population genetics allows us to solve the most diverse range of problems, including in the context of population subdivision. Russian and foreign scientists has repeatedly proven informativeness of surnames as quasigenetic markers in the study of genetic and demographic characteristics of populations, as well as a good comparability of results obtained by using the pool of surnames and genetic markers [11, 33-36]. However, duration of the use of surnames is of importance to adequately characterize the population based on surnames.

The Khakass surnames consolidation process lasted for all the XVIII century, but in general they originate from names of ancestors who lived in the middle of the XVIII century. Surnames were spread among Khakass in that period, when division into separate groups (Kachins, Koybals, Kyzyls, Sagays and others) was clear, so each sub-ethic group has developed its own special pool of surnames [20]. 
Originality of anthroponymycon of Khakass subethnic groups is confirmed, for example, by comparative analysis of the five most common surnames. Each of them

Table 4. Range of the most common surnames in Khakass sub-ethnic groups

\begin{tabular}{|l|c|c|}
\hline Sub-ethnic group & Surnames & Frequency, \% \\
\hline \multirow{5}{*}{ Kachins } & Kokov & 5.61 \\
& Sarazhakov & 5.49 \\
& Kongarov & 4.30 \\
& Chaptykov & 4.26 \\
& Spirin & 4.22 \\
& $\Sigma$ & 23.88 \\
\hline \multirow{4}{*}{ Koybals } & Alahtaev & 16.50 \\
& Chichinin & 11.50 \\
& Kystoyakov & 11.00 \\
& Kapsargin & 9.50 \\
& Kurgundaev & 7.50 \\
& $\Sigma$ & 56.00 \\
\hline \multirow{5}{*}{ Kyzyls } & Yangulov & 10.58 \\
& Achisov & 6.57 \\
& Sulekov & 6.57 \\
& Taydonov & 5.11 \\
& Salamachev & 3.65 \\
& $\Sigma$ & 32.48 \\
\hline \multirow{5}{*}{ Sagays } & Chebodayev & 3.94 \\
& Borgoyakov & 3.50 \\
& Moynagashev & 3.47 \\
& Sagalakov & 3.19 \\
& Topoev & 3.11 \\
& $\Sigma$ & 17.21 \\
\hline
\end{tabular}

includes a very special range of names, characterized by a sufficiently high total frequency in "Top-5" (Table 4) that is an average a third part of the whole pool of surnames.

Special attention should be paid to the Sagay's fund of surnames. Surnames of Beltyr (Asochakov, Sagalakov, Chebodayev, Chuchunov) and Biryusinsk (Akhpashev, Borgoyakov, Moynagashev, Sunchugashev, Tolmashev, Topoev, Ugdyzhekov) genera were enough common among them (surnames classification of V.Ya. Butanaev [1994]). Analysis of the structure of Sagay surnames showed that "beltyr" surnames account for $25 \%$ of the total pool of Sagay surnames, Biryusins surnames account for $58 \%$ and only $17 \%$ falls on "Sagay" surnames themselves. That is, a mixed anthroponymycon of Sagays bears traces of assimilation of Beltyrs and Biryusins.

In general, the Khakass pool of surnames was very diverse: this study revealed more than 700 variants of Khakass surnames (Table 1). This is significantly higher than that of other peoples of Southern Siberia Northern Altaians (432) and Shors (189) [21]. The study also found that the same surnames, despite strengthening of inter-ethnic mixing processes [21], are rarely registered in the pool of surnames of various Khakass sub-ethnic groups (Table 5). This limits the possibility to evaluate the genetic distances between sub-ethnic groups with the use of the Nei method. Therefore, another measure was used for comparison isonymy kinship coefficient $(R i)$, Table 5.

Table 5. The number of common surnames (above the diagonal) and isonymy kinship coefficient $R i$ (below the diagonal) in Khakass sub-ethnic groups (data from household books)

\begin{tabular}{|l|c|c|c|c|}
\hline \multicolumn{1}{|c|}{ Sub-ethnic groups } & Kachins & Koybals & Kyzyls & Sagays \\
\hline Kachins & & 10 & 5 & 27 \\
\hline Koybals & $5.27^{*} 10^{-6}$ & & 1 & 15 \\
\hline Kyzyls & $3.85^{-6} 10^{-6}$ & $4.56^{*} 10^{-6}$ & & 10 \\
\hline Sagays & $2.93 * 10^{-6}$ & $2.82 * 10^{-6}$ & $2.74 * 10^{-6}$ & \\
\hline
\end{tabular}

Describing the isonymy coefficient in Khakass subethnic groups, it is necessary to emphasize that its values were not high $\left(1.43 * 10^{-6}<R i<5.27^{*} 10^{-6}\right)$ : an order of magnitude lower than that of the northern Altaians $\left(19.90 * 10^{-6}<R i<38.63 * 10^{-6}\right)$ and Shors $\left(19.38 * 10^{-6}\right)$ [37]. This indicates significant heterogeneity in the surname composition of Khakass sub-ethnic groups.

Let us emphasize that analysis of the pool of surnames gave a characteristic of genetic relationships of Khakass sub-ethnic groups that is close to characteristic obtained according to a study of autosomal DNA markers. Thus, kinship coefficient $R i$ was the lowest in a pair of "Sagays - Kyzyls" $\left(2.74 * 10^{-6}\right)$, confirming differences in their gene pools, and the highest in the pair "Koybals- Kachins" (5.27* 10-6), confirming similarity of their gene pools. If we rank subethnic groups by increasing similarity of surname composition (and therefore, similarity of gene pools), it is the same as according to data on autosomal DNA markers: Sagays $\left(2.83 * 10^{-6}\right)-$ Kyzyls $\left(3.72 * 10^{-6}\right)-$ Kachins $\left(4.02 * 10^{-6}\right)-$ Koybals $\left(4.45^{*} 10^{-6}\right)$.

\section{CONCLUSION}

Thus, the study on genetic structure of the Khakass sub-ethnic groups according to autosomal DNA markers and pool of surnames, as well as previous study of their gene pools according to data of Y-chromosome polymorphism [9, 23] indicate the persisting genetic originality of Khakass sub-ethnic groups. Apparently, each Khakass sub-ethnic group formed with the participation and contribution of the various ethnic components. This is confirmed by statistically significant differences of allele frequencies of the studied complex of autosomal DNA markers, genetic distances between sub-ethnic groups and high values of inter-population subdivision of Khakass. An amazing for Siberian peoples variety of Khakass anthroponymycon and originality of the pool of surnames of each of the studied Khakass sub-ethnic groups also speaks in favor of reality of their existence and the need to consider sub-ethnic division in the planning of population genetic studies. 


\section{ACKNOWLEDGEMENTS}

In conclusion, let us note that both classes of markers - genetic and quasigenetic - demonstrated Khakass heterogeneity and genetic reality of Khakass sub-ethnic groups- Kachins, Koybals, Kyzyls, and Sagays. In addition, the results obtained in this study once again confirm the informative value of the pool of surnames as a specific marker system in human population genetics.
The study was supported by the state assignment of the Ministry of Education and Science of the Russian Federation no.2014/24

The authors would like to express their sincere gratitude to the Minister of National and Regional Policy of the Republic of Khakassia (2007-2013) Balahchina N. P., as well as employees of the Ministry for their invaluable assistance in organizing and conducting the study.

\section{REFERENCES}

1. Rychkov Yu.G. Osobennosti serologicheskoy differentsiatsii narodov Sibiri [Features of the Serological Differentiation of the Peoples of Siberia]. Voprosy antropologii [The problems of anthropology], 1965, no. 21, pp. 18-33.

2. Lavryashina M.B., Ul'yanova M.V., Vasinskaya O.A., Frolova S.A., Dibirova Kh.D., Balanovskaya E.V. Geneticheskiy portret desyati malykh narodov Yuzhnoy Sibiri [A genetic portrait of ten small nations of soutehrn Siberia]. Meditsinskaya genetika [Journal of Medical Genetics], 2010, vol. 9, no. 3, pp.12-17.

3. Solopekin N.V., Lavryashina M.B., Ul'yanova M.V., Tolochko T.A., Larionov A.V., Meyer A.V., Minina V.I., Druzhinin V.G. Issledovanie riska podverzhennosti alkogolizmu korennogo naseleniya yuga Zapadnoy Sibiri po dannym molekulyarnogeneticheskikh markerov [The study of alcohol addiction risk in the indigenous population of southwest siberia according to molecular genetic markers]. Vestnik Kemerovskogo gosudarstvennogo universiteta [Bulletin of Kemerovo State University], 2013, vol. 1, no. 1, pp. 39-43. doi: 10.21603/2078-8975-2013-1-39-43.

4. Derenko M.V., Malyarchuk B.A. Molekulyarnaya filogeografiya naseleniya Severnoy Azii po dannym ob izmenchivosti mtDNK [Molecular phylogeography of native population of the North Asia according to data on mitochondrial DNA variability]. Institute of Biological Problems of the North: FEB RAS, 2010. 376 p.

5. Mazulin I.Yu. Izmenchivost' mitokhondrial'noy DNK tubalarov Gornogo Altaya i evenov Vostochnoy Sibiri. Avtoref. diss. kand. biol. nauk [Mitochondrial DNA variation for Tubalars of the Altai Mountains in Evens in Eastern Siberia. Cand. biol. sci.]. Novosibirsk, 2010. 18 p.

6. Volkov V.G., Khar'kov V.N., Shtygasheva O.V., Stepanov V.A. Geneticheskoe issledovanie khakasskikh i teleutskikh seokov. Sravnitel'naya kharakteristika po dannym markerov Y-khromosomy [Genetic study of Khakass Teleut. Comparative characteristics Ychromosome markers.]. Kul'tura kak sistema v istoricheskom kontekste: opyt Zapadno-Sibirskikh arkheologo-etnograficheskikh soveshchaniy: materialy XV Mezhdunarodnoy Zapadno-Sibirskoy arkheologo-etnograficheskoy konferentsii, Tomsk, 19-21 maya $2010 \mathrm{~g}$ [Culture as a system in its historical context: the experience of the West Siberian archaeological and ethnographic meetings: proceedings of the XV International West Siberian archaeological and ethnographic conference, Tomsk, 19-21 May 2010], 2010. pp. 403-405.

7. Balaganskaya, O.A. Geneticheskaya struktura po markeram Y khromosomy narodov Altaya (Rossii, Kazakhstana, Mongolii) [GenePool Structure of Altai people (Russia, Kazakhstan, Mongolia) Inferred from Y-Chromosome Marker Data]. Vestnik Moskovskogo universiteta. Seriya XXIII. Antropologiya [Bulletin of Moscow University. Series XXIII. Anthropology], 2011, no. 2, pp. 23-36.

8. Khar'kov V.N., Khamina K.V., Medvedeva O.F., Shtygasheva O.V., Stepanov V.A. Raznoobrazie genofonda khakasov: vnutrietnicheskaya differentsiatsiya i struktura gaplogrupp Y-khromosomy [Genetic diversity of the Khakass gene pool: Subethnic differentiation and the structure of Y-chromosome haplogroups]. Molekulyarnaya biologiya [Molecular biology], 2011, vol. 45, no. 3, pp. 446-458

9. Balanovskaya E.V. Vliyanie prirodnoy sredy na formirovanie genofonda tyurkoyazychnogo naseleniya gor i stepnykh predgoriy Altae-Sayan, Tyan'-Shanya i Pamira [Impact of the environment on the gene pool of Turkic-speaking populations of mountains and steppes in Altay, Sayan, Tien Shan and Pamir]. Vestnik Moskovskogo universiteta. Seriya XXIII ANTROPOLOGIYA [Bulletin of Moscow University. Series XXIII. ANTHROPOLOGY], 2014, no. 2, pp. 46-55

10. Vagaytseva K.V., Khar'kov V.N., Cherpinskaya K.V., Khitrinskaya I.Yu., Stepanov V.A. Geneticheskaya variabel'nost' Xstseplennykh STR-markerov v populyatsiyakh Sibiri [Genetic Variability of X Linked STR Markers in Siberian Populations]. Molekulyarnaya biologiya [Molecular biology], 2015, vol. 49, no. 2, pp. 305-312. doi: 10.7868/S0026898415020147.

11. Lavryashina, M.B. Shortsy: skhodstvo i razlichie territorial'nykh grupp po dannym fonda familiy i autosomnykh DNK markerov [Shor people: similarities and differences between territorial groups according to the pool of surnames and autosomal DNA markers]. Vestnik Moskovskogo universiteta. Seriya XXIII. Antropologiya [Bulletin of Moscow University. Series XXIII. Anthropology], 2011, no. 2, pp. 66-77.

12. Ul'yanova M.V. Lavryashina M.B., Nikolaev V.V. Famil'nyy analiz kak instrument otsenki dinamiki geneticheskoy struktury populyatsiy severnykh altaytsev [Surname analysis as a tool to assess dynamics of genetic structure of populations of the northern Altai]. VOGiS i assotsiirovannye geneticheskie simpoziumy: tezisy dokladov, Rostov na Donu 15-20 iyunya 2014 g. [VI Congress of Vavilov Society of geneticists and breeders and associated genetic workshops: abstracts, Rostov-on-Don, 15-20 June 2014]. Novosibirsk: "SB RAS Publishing House", 2014, 91 p.

13. Balanovskaya E.V., Zhabagin M.K., Agdzhoyan A.T. Populyatsionnye biobanki: printsipy organizatsii i perspektivy primeneniya $\mathrm{v}$ genogeografii i personalizirovannoy meditsine [Population biobanks: organization principles and prospects of application in gene geography and personalized medicine]. Genetika [Genetics], 2016, no. 12.

14. Raghavan M., Steinrücken M., Harris K. Genomic evidence for the Pleistocene and recent population history of Native Americans. Science, 2015, vol. 349, no. 6250. doi: 10.1126/science.aab3884.

15. Knappskog S., Gansmo L., Dibirova K. Population distribution and ancestry of the cancer protective mdm2 snp285 (rs117039649). Oncotarget, 2014, vol. 18, no. 5, pp. 8223-8234. doi: 10.18632/oncotarget.1910.

16. Kyzlasov L.R. Istoriya Yuzhnoy Sibiri v srednie veka [History of Southern Siberia in the Middle Ages]. Moscow, 1984,52 p.

17. Butanaev V.Ya. Vopros o samonazvanii khakasov [Question of the self-designation of Khakases]. Etnograficheskoe obozrenie [Ethnographic Review], 1992, pp. 63-69. 
18. Butanaev V.Ya Etnicheskaya istoriya khakasov XVII-XIX vv. [Ethnic history of Khakases in the XVII-XIX centuries]. Materialy k serii "Narody Sovetskogo Soyuza". Vyp. 3. Khakasy [Materials for the series "The peoples of the Soviet Union". Issue 3. Khakass]. Moscow, 1990, 15 p.

19. Butanaev V.Ya. Proiskhozhdenie khakasskikh rodov i familiy [Origin of Khakassian genera and surnames]. Abakan, 1994. 93 p.

20. Krivonogov V.P. Etnicheskie protsessy u malochislennykh narodov Sredney Sibiri [Ethnic processes of small-numbered peoples in Central Siberia]. Krasnoyarsk: KSPU Publ., 1998, 320 p.

21. Lavryashina M.B., Ul'yanova M.V., Balanovskaya E.V. Vliyanie genetiko-demograficheskikh protsessov na strukturu sel'skikh populyatsiy korennogo naseleniya Yuzhnoy Sibiri: tri neperekryvayushchikhsya pokoleniya po dannym o demografii i rasprostranennosti familiy [The influence of demographic processes on population-genetic structure in rural populations of native people of Southern Siberia: the three non-overlapping generations on data of demography and surnames distribution]. Meditsinskaya genetika [Medical Genetics], 2010, vol. 9, no. 4, pp. 16-24.

22. Bagashev A.N. Rasogenez korennogo naseleniya [Race genesis of the indigenous population]. Tomsk: TSU Publ., 1998, 354 p.

23. Balaganskaya O.A., Balanovskaya E.V., Lavryashina M.B., Isakova Zh.T. Polimorfizm Y khromosomy u tyurkoyazychnogo naseleniya Altaye-Sayan, Tyan'-Shanya i Pamira v kontekste vzaimodeystviya genofondov zapadnoy i vostochnoy Yevrazii [Y-chromosomal polymorphism in Turkic-speaking populations from Altai-Sayan, Tien-Shan and Pamir mountains in context of the interaction between western and eastern Eurasian gene pools]. Meditsinskaya genetika [Medical Genetics], 2011, vol. 10, no. 3, pp. 12-22.

24. Lasker G.W. A coefficient of relationship by isonymy: a method for estimating the genetic relationship between populations. Human. Biol., 1977, vol. 49, no. 3, pp. 489-493.

25. Nei M. Molecular evolutionary genetics. Amsterdam, 1975. 278 p.

26. Balanovsky O., Rootsi S., Pshenichnov A., Kivisild T., Churnosov M. Two sources of the Russian patrilineal heritage in their Eurasian context. Am. J. Hum. Genet, 2008, vol. 82, pp. 236-250.

27. Kofiadi I.A. Geneticheskaya ustoychivost' k zarazheniyu VICh i ustoychivost' SPID v populyatsiyakh Rossii i sopredel'nykh gosudarstv: Avtoref. dis. kand. biol. nauk [Genetic resistance to HIV infection and AIDS stability in populations of Russia and neighboring countries. Cand. biol. sci.]. Moscow, 2008, 23 p.

28. Liu M., Wang F., Jin L., Hong W., Lei Z., Zhang B., Hou J., Zhang B., Hou J., Zhang, Tang. C. Characterization of CCR5 del32, CCR2b-64I, CXCR1-249I280M and SDF1-3'A Allelic polymorphisms in the Chinese Uygur Population. Chinese Journal of Sexually Transmitted Infections, 2002, no. 2, pp. 7-11.

29. Su B., Sun G., Lu D., Xiao J., Hu F., Chakraborty R., Deka R., Jin L. Distribution of three HIV-1 resistance-conferring polymorphisms (SDF1-3'A, CCR2-641, and CCR5-delta32) in global populations. Eur. J. Hum. Genet., 2000, no. 8, pp. $975-979$.

30. Voevoda M.I. Polimorfizm i svyaz's faktorami riska nekotorykh genov predraspolozhennosti $k$ serdechnososudistym zabolevaniyam v etnicheskikh gruppakh Sibiri. Evolyutsionno-geneticheskie i molekulyarno-epidemiologicheskie aspekty. Diss. dokt. med. nauk [Polymorphism and linkage with risk factors of some susceptibility genes to cardiovascular diseases in ethnic groups of Siberia, molecular epidemiological and evolutionary-genetic aspects. Dr. med. sci. diss.]. Novosibirsk, 2002,50 p.

31. Kozhekbaeva G.M., Borodina T.A., Borinskaia S.A., Gusar V.A., Feshchenko S.P., Akhmetova V.L., Khusainova R.I., Gupalo E.Iu., Spitsyn V.A., Grechanina E.Ia., Khusnutdinova K., Iankovskii N.K. Distribution of the HIV-1 resistance-conferring alleles (CCR5delta32, CCR2-64I, and SDF1 3'A) in Russian, Ukrainian, and Belarusian populations. Genetika, 2004, vol. 40, pp. $1394-1401$.

32. Lavryashina M.B., Ul'yanova M.V., Balaganskaya O.A., Balaganskiy A.G., Balanovskaya E.V. Geneticheskiy portret desyati malykh narodov Yuzhnoy Sibiri [A genetic portrait of ten small nations of soutehrn Siberia]. Meditsinskaya genetika [Medical Genetics], 2010, vol. 99, no. 9, pp. 16-23.

33. Balanovskaya E.V., Balanovskiy O.P. Russkiy genofond na russkoy ravnine [Russian gene pool in the Russian plain]. Moscow: Luch Publ., 2007, 416 p.

34. El'chinova G.I., Zinchenko R.A. Dopustimost' ispol'zovaniya tatarskikh familiy v kachestve kvazigeneticheskogo markera $\mathrm{v}$ populyatsionno-geneticheskikh issledovaniyakh [Possibility to use tatar surnames as a quasigenetic marker in population-genetic researches]. Vestnik MGU. Seriya XXIII. Antropologiya [Bulletin of Moscow State University. Series XXIII. Anthropology], 2010, no. 2, pp. 55-61.

35. Turi E. Kingemail, Mark A. Jobling What's in a name? Y chromosomes, surnames and the genetic genealogy revolution. Trends in genetics, 2009, vol. 25, no. 8, pp. 351-360. doi: http://dx.doi.org/10.1016/j.tig.2009.06.003.

36. Calderon R., Hernandez C.L., Cuesta P., Dugoujon J.M. Surnames and Y-Chromosomal Markers Reveal Low Relationships in Southern Spain. PLoS One, 2015, vol. 10, no. 4. doi: 10.1371/journal.pone.0123098.

37. Lavryashina M.B. Kompleksnoe issledovanie dinamiki demograficheskikh protsessov i struktury genofonda korennykh narodov Yuzhnoy Sibiri. Diss. doct. biol. nauk [A comprehensive study of dynamics of demographic processes and structure of the gene pool of the indigenous populations of Southern Siberia. Dr. biol. sci. diss.]. Moscow, 2012, 56 p.

\section{Maria B. Lavryashina}

Dr.Sci.(Biol.), Professor, Department of Genetics, Kemerovo State University, Kemerovo, Russian Federation

Marina V. Ul'yanova

Cand.Sci.(Biol.), Department of Genetics, Kemerovo State University, Kemerovo, Russian Federation

\section{Olga A. Balaganskay}

Cand.Sci.(Biol.), Senior Research Fellow, Vavilov Institute of General Genetics, Russian Academy of Sciences, Moscow, Russian Federation

Elena V. Balanovska

Dr.Sci.(Biol.), Professor, Medical Genetics Research Center, Moscow, Russian Federation 